\title{
Under the skin: Ixodes ticks in the subcutaneous tissue of red foxes (Vulpes vulpes) from Germany
}

\author{
Maja Haut ${ }^{1}$, Nina Król ${ }^{1}$, Anna Obiegala', Johannes Seeger ${ }^{2}$ and Martin Pfeffer ${ }^{1 *}$
}

\begin{abstract}
Background: Ixodes spp. are vectors of zoonotic pathogens. All three active life stages (larvae, nymphs, adults) need to feed on a host in order to develop. Usually ticks parasitize attached to the external surface of their hosts' skin. Interestingly, in some cases ticks can also be found in the subcutaneous tissue in a variety of hosts, such as red foxes (Vulpes vulpes), raccoon dogs (Nyctereutes procyonoides) and dogs.

Methods: The visceral side of 126 red fox-furs from Germany was examined visually searching for ticks. The localization of ticks was recorded and assigned to ten specific body parts. Morphological identification of ticks was performed according to standardized taxonomic protocols. Ticks which could not be further identified were examined genetically via conventional PCR targeting the $16 \mathrm{~S}$ rRNA and cox1 gene. Hematoxylin and eosin (H\&E) staining was used for histopathological examination.
\end{abstract}

Results: In 111 out of 126 (88.1\%) examined coats, at least one tick was found in the subcutaneous tissue. A total of 1203 ticks were removed from the subcutaneous tissue. Well-preserved ticks could be identified based on morphological criteria, but most ticks were in a progressed state of decomposition. Here, morphological species identification was not successful. Also, PCR methods did not lead to a successful species identification. The following species and development stages were found by morphological identification: Ixodes ricinus (female, $n=289$; male, $n=8$; nymph, $n=1$ ), I. hexagonus (female, $n=2$ ), I. canisuga (female, $n=1$ ). Male I. ricinus were found individually or copulating in pairs with females. Subcutaneous ticks were localized at three predominant affected body parts: ears, axillar and inguinal region. Histological examination of subcutaneous ticks revealed a granulomatous panniculitis.

Conclusions: To the authors' knowledge, this is the first finding of highly prevalent subcutaneous ticks in red foxes from Germany. Subcutaneous location of ticks seems to be very common in red foxes and the rule rather than the exception. Deep embedment of longirostra and long feeding times of females seem to put the subcutaneous location in favor. Most foxes were infested in the inguinal area, where the skin is thin and less hairy.

Keywords: Ectoparasites, Subcutaneous, Ixodes spp., Tick, Red fox, Germany, Europe

\footnotetext{
*Correspondence: Pfeffer@vetmed.uni-leipzig.de

${ }^{1}$ Institute of Animal Hygiene and Veterinary Public Health, Faculty of Veterinary Medicine, University of Leipzig, An den Tierkliniken 1, 04103 Leipzig, Germany

Full list of author information is available at the end of the article
}

\section{Background}

Ticks belonging to the genera Ixodes and Dermacentor (Family: Ixodidae) are the most prevalent in Europe [1]. All active tick life stages (six-legged larva, eight-legged nymph and females) require blood meals from hosts for molting (immatures) or for oviposition (females) with the exception of males which feed facultatively and are localized on hosts mainly for mating purposes [1,2].

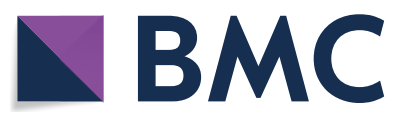

(c) The Author(s) 2020. This article is licensed under a Creative Commons Attribution 4.0 International License, which permits use, sharing, adaptation, distribution and reproduction in any medium or format, as long as you give appropriate credit to the original author(s) and the source, provide a link to the Creative Commons licence, and indicate if changes were made. The images or other third party material in this article are included in the article's Creative Commons licence, unless indicated otherwise in a credit line to the material. If material is not included in the article's Creative Commons licence and your intended use is not permitted by statutory regulation or exceeds the permitted use, you will need to obtain permission directly from the copyright holder. To view a copy of this licence, visit http://creativeco mmons.org/licenses/by/4.0/. The Creative Commons Public Domain Dedication waiver (http://creativecommons.org/publicdomain/ zero/1.0/) applies to the data made available in this article, unless otherwise stated in a credit line to the data. 
In Germany the species Ixodes ricinus, I. hexagonus, I. canisuga and I. kaiseri have been frequently collected from foxes [3-8]. Additionally, Dermacentor reticulatus and Haemaphysalis concinna were occasionally found attached to red foxes' skin [7, 9]. Ticks are usually strongly attached to the external surface of their hosts to remain in place for a blood meal. Thereby tick' mouthparts penetrate different skin layers, depending on their length. Ticks with long mouthparts (longirostra e.g. Amblyomma, Hyalomma and Ixodes) embedded into deep layers of the dermis while ticks with short mouthparts (brevirostra e.g. Dermacentor, Haemaphysalis and Rhipicephalus) barely penetrate the epidermis [10, 11]. Ixodes ricinus larvae are attached for 2-4 days, nymphs for 4-6 days and females for 6-10 days [12].

Interestingly, in some cases ticks can also be found in the subcutaneous tissue in a variety of hosts including red foxes. The presence of subcutaneous ticks such as $I$. ricinus, $I$. hexagonus, $I$. crenulatus and D. reticulatus was noted in red foxes in several case studies from the UK, Poland, Austria, Romania, Slovakia and Czech Republic [13-20]. In the USA, the native tick species Amblyomma americanum was likewise discovered in the subcutaneous tissue of red foxes [21].

Besides red foxes, single case reports of subcutaneous ticks were previously recorded in raccoon dogs $(\mathrm{Nyc}-$ tereutes procyonoides) from Poland [22], in a dog from Sweden [23] and in a child from South Korea [24].

Hitherto, small sample sizes were reported in most cases also rather as occasional findings [13-17, 21]. Thus far, no published data exist about subcutaneous ticks in red foxes or other animals from Germany. This is why this study is aiming to evaluate the frequency of subcutaneous ticks in red foxes from Germany using a large number of samples. The localization of subcutaneous ticks at different body regions of the red fox has not been analyzed yet; therefore, we documented the localization of each tick in order to determine the abundance of these ticks in the subcutaneous tissue. Precise species identification of subcutaneous ticks based on morphological criteria is possible only to a limited extent due to the advanced degradation process in subcutaneous tissue, as seen in previous studies [18]. Hence, this study aims to use molecular biology techniques to identify subcutaneous ticks to species level.

\section{Methods}

\section{Animal collection}

Between November 2018 and February 2019 local hunters shot red foxes and other wild game in course of traditional hunting. In cooperation with a scrape station (Fellwechsel Berlin, Germany), local hunters from all over Germany deposited fox carcasses in plastic bags labelled with the date and exact geographical location in deep-freezers. Only adult foxes with good nutritional status were selected by hunters. Fox cadavers were stored at $-80{ }^{\circ} \mathrm{C}$ until flaying. For enabling the histological studies one fox was skinned directly after hunting.

\section{Tick collection and identification}

The visceral side of each fur was examined visually for the presence of subcutaneous ticks. The localization of ticks was recorded on a pre-drawn schematic picture and assigned to ten specific body parts (ears, neck, axillar region, shoulder, back, belly, inguinal region, anorectal region, legs and tail) in order to create a body map of tick density (Fig. 1), as recommended by Lydecker et al. [25]. Afterwards, the ticks were individually dissected from the subcutaneous tissue with fine-tipped forceps and a scalpel and stored at $-20{ }^{\circ} \mathrm{C}$ (Fig. 2). Well-preserved ticks could be identified based on morphological criteria according to standardized taxonomic protocols [26] under a binocular at 50× magnification (Motic SMZ-171, Motic Deutschland GmbH, Wetzlar, Germany).

\section{DNA extraction and PCR methods}

Ticks which could not be morphologically identified were further processed by conventional PCR to identify them to species level. For the DNA extraction, $1 \mathrm{~g}$ of steel beads (sized $2.8 \mathrm{~mm}$ ) and $500 \mu \mathrm{l}$ of PBS were added to each tick. The samples were then homogenized at $5000 \times \mathrm{rpm}$ for $2 \times 15 \mathrm{~s}$ with $15 \mathrm{~s}$ break intervals in a Precellys ${ }^{\circledR} 24$ tissue homogenizer (Bertin Technologies, Montigny Le Bretonneux, France).

The genomic DNA was extracted using the QIAamp DNA Mini Kit (Qiagen, Hilden, Germany) following the manufacturer's instructions. PCR amplifications of partially cytochrome $c$ oxidase subunit 1 (cox1) gene (710 $\mathrm{bp}$ ) and of the $16 \mathrm{~S}$ ribosomal ribonucleic acid (rRNA) gene (455 bp) were performed using previously published PCR protocols $[8,27]$. PCR products were visualized by gel electrophoresis on $2 \%$ agarose gels stained with HDGreen Plus DNA Stain (Intas Science Imaging Instruments GmbH, Göttingen, Germany).

\section{Histological examination of subcutaneous tissue}

Subcutaneously located ticks were removed with the skin and the surrounding tissue from the complete fur and immediately fixed in $10 \%$ buffered formalin, dehydrated in ascending ethanol series (20-100\%) and embedded in paraffin blocks. Seven-micron thick sections were cut with a rotary microtome (Leica RM 2155, Leica Microsystems Nussloch GmbH, Nussloch, Germany), placed on glass slides and stained with hematoxylin and 
VENTRAL

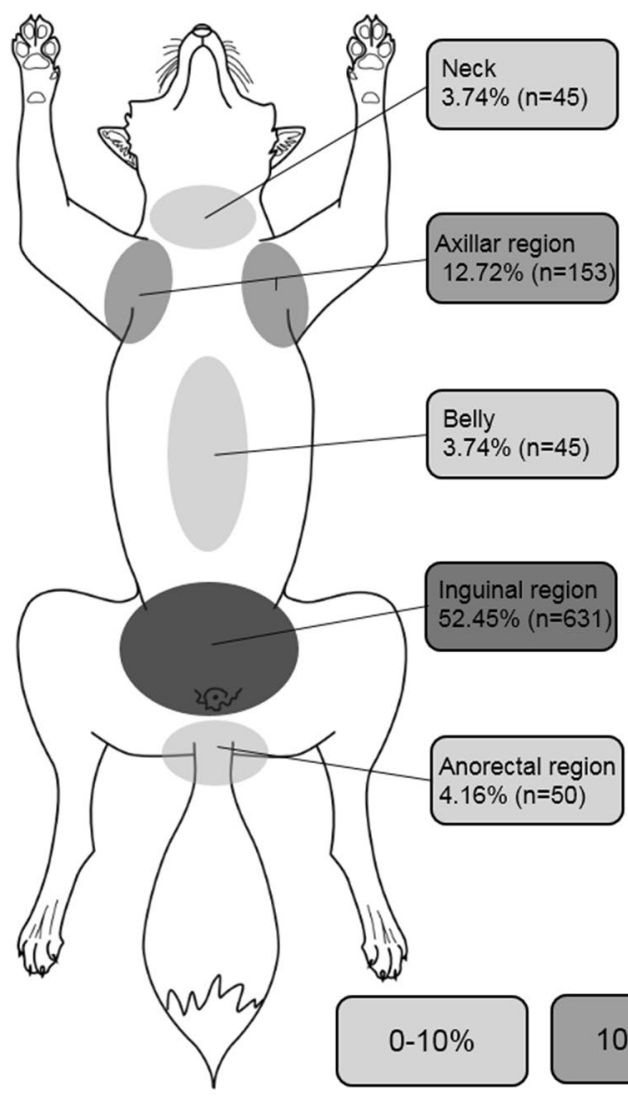

DORSAL

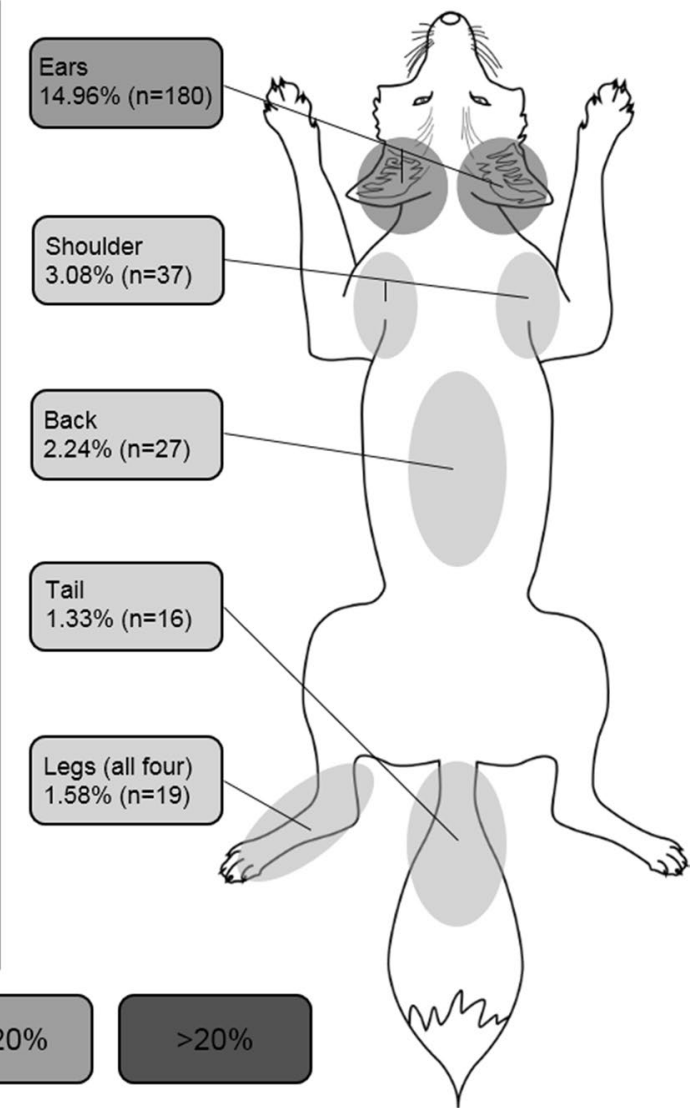

Fig. 1 Density of ticks expressed as percentage of total number of ticks depending on body region ( $n=111$ red foxes). A darker grey in the figure indicates a higher density of ticks

eosin $(\mathrm{H} \& \mathrm{E})$. Microscopy and pictures were performed using a Zeiss Axioplan 2 imaging (Carl Zeiss Microscopy, Jena, Germany) equipped with an objective $25 \times / 0.8$ PlanNeofluar Oil and a color camera ProgRes C14 (Jenoptik, Jena, Germany). Whole section overviews were obtained by tile scans with a $25 \times / 0.8$ Plan-Neofluar Oil objective using a tile scan routine under Openlab 5.5 (Improvision, Coventry, UK). During histological examination it was noticed that the inflammatory response was related to the stage of degradation of the tick. Therefore, the ticks were divided into 3 categories: (i) well-preserved ticks with correct position of hypostome and the appendages and intact exoskeleton and body; (ii) deformed ticks with intact exoskeleton; and (iii) ticks with broken, fully deformed exoskeleton.

\section{Statistical analysis}

Confidence intervals (95\% CI) for prevalence rates of subcutaneous ticks and their life stage were determined by the Clopper \& Pearson method with GraphPad Software (GraphPad Software Inc., San Diego, CA, USA). The Mann-Whitney U-test with a significance level of $\alpha=0.05$ was used to compare the different body regions. The independence of compared small sample sizes $(n<30)$ was tested with Fisher's exact test. Statistical analyses were performed using IBM SPSS Statistics for Windows, Version 25.0 (IBM Corp, Armonk, NY, USA).

\section{Results}

\section{Animal collection}

For the present study 126 red foxes (75 males and 51 females), were collected and examined from central [federal states of Brandenburg ( $n=1)$; Hessen $(n=2)$; North Rhine-Westphalia $(n=56)$ : Saxony $(n=3)$; and Thuringia $(n=5)$ ] and northern Germany [federal states of Lower Saxony $(n=45)$; and Schleswig-Holstein $(n=14)]$. 

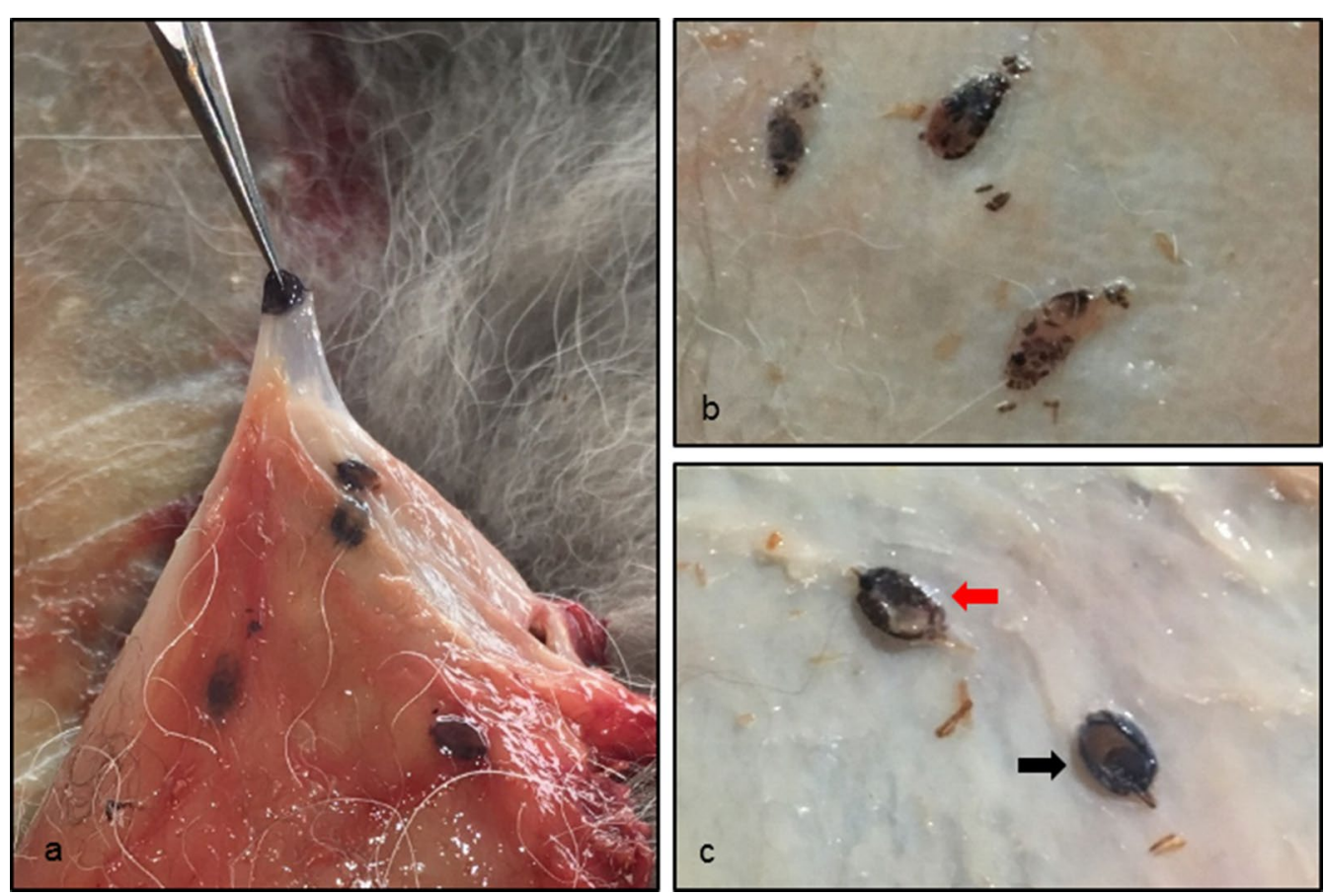

Fig. 2 Macroscopic view on ticks with subcutaneous localization. a One tick lifted up with a fine-tipped forceps and other ticks in the surrounding tissue. b Ticks in advanced stages of decomposition. c Well-preserved ticks in dorsal (black arrow) and ventral positon (red arrow)

\section{Tick collection}

In 111 out of 126 (88.1\%, 95\% CI: 81.13-93.18\%) examined coats, at least one tick was found in the subcutaneous tissue. The frequency of the occurrence of subcutaneous ticks between male and female foxes did not differ significantly $(P<0.590)$. The tick burden per fox varied from 1 to 79 , with a mean of $10.8(\mathrm{SD}=14.02)$. Most of the foxes $(69.0 \%)$ were infested with a maximum of 10 ticks (Fig. 3). A total of 1203 ticks were removed

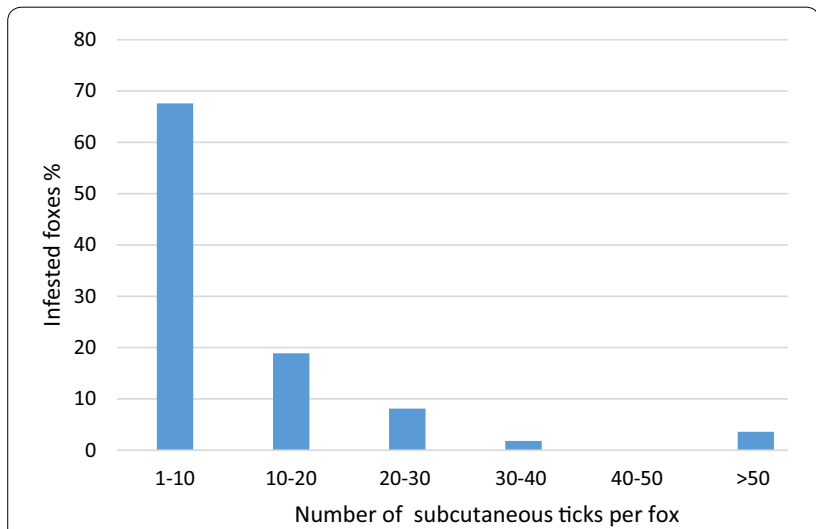

Fig. 3 The distribution of tick burden diverged between 1 to 79, a total of 1203 ticks could be removed. Most of the foxes were infested with only a small number of ticks from the subcutaneous tissue. Morphological features of the Ixodidae, like the presence of a dorsal scutum or mouthparts anteriorly attached and visible dorsally, were present in all ticks found. Most ticks $(n=902 ; 75 \%)$ were in a progressed state of decomposition and the developmental stage as well as the species level could not be determined. However, specific criteria were met to assign the ticks to the family Ixodidae. In these cases, species identification using molecular biological methods was not successful. Well-preserved ticks $(n=301 ; 25.0 \%)$ could be identified to the species level based on morphological criteria. The following species and developmental stages were found (Table 1): Ixodes ricinus (female, male, nymph); I. hexagonus (female); I. canisuga (female). The most prevalent life stage were females $(97.0 \%$; $n=292 / 301$, 95\% CI: $94.40-98.62 \%)$ followed by males

Table 1 Tick species and life stages of well-preserved ticks found in the subcutaneous tissue

\begin{tabular}{lllll}
\hline Tick species & $\begin{array}{l}\text { No. of ticks } \\
(\%)\end{array}$ & No. of males & $\begin{array}{l}\text { No. of } \\
\text { females }\end{array}$ & No. of nymphs \\
\hline I. ricinus & $298(99.0)$ & 8 & 289 & 1 \\
I. hexagonus & $2(0.7)$ & 2 & 1 & \\
I. canisuga & $1(0.3)$ & & $292(97.0)$ & $1(0.3)$ \\
Total (\%) & $301(100)$ & $8(2.7)$ & & \\
\hline
\end{tabular}


(2.7\%; $n=8 / 301,95 \%$ CI: $1.15-5.17 \%)$ and nymphs $(0.3 \%$; $n=1 / 301$, 95\% CI: 0.01-1.84\%). Females were identified most frequently as $I$. ricinus $(99.0 \% ; n=289 / 292,95 \%$ CI: 97.03-99.79\%). All male ticks belonged to I. ricinus and were mainly found as mating pairs with females $(n=6 / 8)$, but also individually $(n=2 / 8)$.

\section{Subcutaneous localization of ticks}

Subcutaneous ticks were localized at all 10 defined body parts. Significantly, most ticks were found in the inguinal area compared to all other body regions $\left(U_{(2268)}=262431.00, \quad Z=-26.629, \quad P<0.001\right)$. Overall, $52.5 \%(n=631 / 1203)$ of all collected ticks were found in this region, distributed among 91 out of 111 infested foxes. Compared to all other regions most foxes were infested with subcutaneous ticks in the inguinal area $(P<0.0059$ to $P<0.0001$; Table 2$)$. The second and third most common body region were the areas around the ears and the axilla. In total, $80.2 \%(n=964)$ of all collected ticks were observed in these three body regions (Fig. 1). Further regions showed a significantly lower burden of subcutaneous ticks $\left(U_{(5292)}=2072521.50\right.$, $Z=-30.909, P<0.001)$. The difference in the distribution of subcutaneous ticks between female and male foxes was not statistically significant for the most frequently infested body parts (inguinal region: $U_{(126)}=1711.00$, $Z=-1.015, P=0.310$; axillar region: $U_{(126)}=1869.00$, $Z=-0.274, P=0.784$; ears $U_{(126)}=1743.50, Z=-0.889$, $P=0.374)$.

\section{Histological studies of subcutaneous tissue}

In total, 23 subcutaneous ticks collected from one fox were histologically examined (Fig. 4). Only one tick was

Table 2 In the majority of fox furs subcutaneous ticks were found in more than one body region. But significantly most foxes were infested in the inguinal region in a direct paired comparison with all other body regions

\begin{tabular}{ll}
\hline Body part & No. of infested foxes (\%) \\
\hline Ears & $69 / 126(54.8)^{* *}$ \\
Neck & $28 / 126(22.2)^{* * *}$ \\
Axillar region & $35 / 126(27.8)^{* * *}$ \\
Shoulder & $20 / 126(15.9)^{* * *}$ \\
Back & $13 / 126(10.3)^{* * *}$ \\
Belly & $21 / 126(16.7)^{* * *}$ \\
Inguinal region & $91 / 126(72.2)$ \\
Anorectal region & $18 / 126(14.3)^{* * *}$ \\
Legs & $13 / 126(10.3)^{* * *}$ \\
Tail & $6 / 126(4.8)^{* * *}$
\end{tabular}

${ }^{*} P \leq 0.05,{ }^{* * P} \leq 0.01,{ }^{* * *} P \leq 0.001$ assigned to category 1, 11 belonged to category 2, and 11 to category 3 . Ticks of category 1 were surrounded by a moderate granulomatous inflammation of subcutaneous fat tissue (panniculitis) consisting of histiocytes, macrophages, multinuclear giant cells and eosinophils. Neutrophils were only occasionally seen. A mild dermal inflammatory response was present with mild exocytosis of inflammatory cells in the epidermis. Histiocytes, macrophages and eosinophils were the most common cells observed. Additionally, moderate epidermal inter- and intracellular edema and moderate lamellar orthokeratotic hyperkeratosis were found. Intradermal and intracorneal pustules filled mainly with neutrophils and rarely with macrophages were present.

A high degree of deformation of ticks was visible in most of the histological sections. The presence of ticks of category 2 resulted in a mild granulomatous panniculitis composed of histiocytes, macrophages, multinuclear giant cells, eosinophils and sparse neutrophils.

In the inner part of the ticks of category 1 and 2 no soft tissue of the arthropod could be identified, and no cellular structures were recognizable. The broken exoskeleton of ticks belonging to category 3 was filled with a mixed inflammatory cell infiltrate consisting of histiocytes, macrophages and multinuclear giant cells. These ticks were surrounded by a severe granulomatous panniculitis without inflammatory changes of dermis and epidermis.

Histological examination of ticks with surrounding tissue and skin confirmed the subcutaneous localization. Increasing eosinophilic granulomatous inflammation from category 1 to 3 were observed. During histopathological examination no blood degradation products were observed.

\section{Discussion}

Foxes are important hosts for a variety of endo- and ectoparasites and thereby reservoirs for animal pathogens and zoonoses [28]. The observed prevalence of subcutaneous ticks $(88.1 \%)$ in the present study is higher than in Poland (38\%) [20] and Czech Republic/Romania (15.4\%) [18]. Moreover, the prevalence of subcutaneous ticks is higher in comparison with external tick prevalence in red foxes from Italy (7.4\%) [29] and Romania (53.9\%) [30], but coincides to studies from Spain (51.1-84.6\%) [31-33] and Germany (76.5-82.6\%) [7, 34]. Additionally, the infestation intensity of subcutaneous ticks $($ mean $=10.8)$ in the present study is similar to external ticks from another study examining 1268 foxes in Germany $($ mean $=11.7$ ) [34]. In that study, $50.9 \%$ of foxes were infested with a maximum of 5 ticks on their external surface, while in the present study $43.2 \%$ of the foxes were infested with a maximum of 5 ticks. However, in some cases both subcutaneous and external ticks were collected numerously 

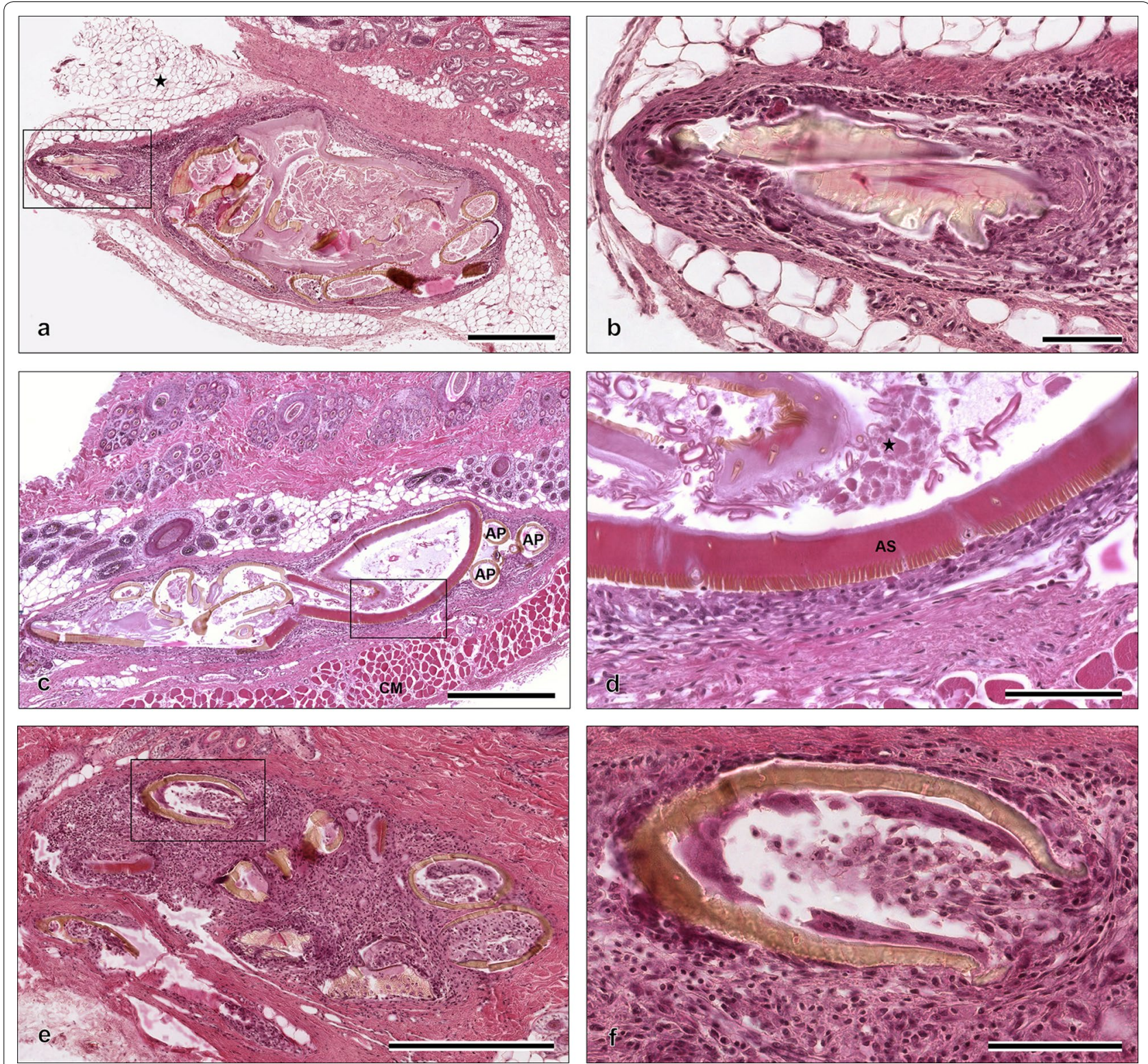

Fig. 4 Histological examination of ticks located in the subcutaneous tissue of a red fox from Germany. a Well-preserved tick of category 1 in the subcutaneous fat tissue (marked by asterisk) (H\&E). $\mathbf{b}$ The hypostome of the tick from $\mathbf{a}$ at a higher magnification. The hypostome is surrounded by a mixture of inflammatory cells and a fibrous capsule (H\&E). c A deformed tick of category 2 in the subcutaneous tissue above the cutaneous muscle (panniculus carnosus) (CM). Three appendages (AP) are visible, but due to high deformation of the tick not assignable to legs or palpi (H\&E). d Magnification of alloscutum (AS), the inner part of the tick and the surrounding inflammation of the tick from $\mathbf{c}$. The inner part of the tick contains of cell debris (marked by asterisk) without any cellular structure (H\&E). e The broken parts of exoskeleton of category 3 tick (H\&E). f Infiltration of broken exoskeleton with inflammatory cells consisting of histiocytes, eosinophils and multinuclear giant cells (H\&E). Scale-bars: $\mathbf{a}, \mathbf{c}, \mathbf{e}, 500 \mu \mathrm{m} ; \mathbf{b}, \mathbf{d}$, f, $100 \mu \mathrm{m}$

from a few foxes $(3.6-5.7 \%)$ with more than 50 ticks per fox [7].

In Europe, several ticks of the genera Ixodes, Dermacentor, Haemaphysalis, Hyalomma and Rhipicephalus are known to parasitize red foxes [7, 8, 29, 31, 32]. In Germany, I. ricinus, I. hexagonus, I. canisuga and I. kaiseri were commonly collected from foxes, while $D$. reticulatus and H. concinna were occasionally found $[7,9]$. Accordingly, we found three of the previously mentioned longirostral species (I. ricinus, I. hexagonus and I. canisuga) in the subcutaneous tissue. Likewise, previously published data from USA and Czech Republic/Romania show regional differences of tick species in the subcutaneous tissue depending on the prevailing tick fauna $[18,20,21]$. 
Longirostra (e.g. Amblyomma, Hyalomma and Ixodes) embed more deeply to the hosts skin in comparison to brevirostra (e.g. Dermacentor, Haemaphysalis and Rhipicephalus) which attach more superficially $[10,11]$. In the current study, exclusively Ixodes ticks were collected from the subcutaneous tissue of the foxes. These findings are in line with published records of subcutaneous ticks, where Ixodes ticks dominated over Dermacentor spp. which were found only occasionally $[18,20]$. The deep embedment (as in longirostra) was previously discussed to be favorable for the subcutaneous location of ticks [18]. Our findings are in line with this assumption as longirostra were significantly more often found subcutaneously in comparison to brevirostra.

The feeding period of ixodid ticks depends on the tick's developmental stage and varies between several days (immatures) up to two weeks (females) [12]. D'Amico et al. [18] highlighted that a long feeding duration is putting ticks in favor of being found in the subcutaneous tissue. In agreement with this, significantly more females were found subcutaneously $(97.0 \%$; $P<0.0001)$ when compared to males and nymphs in the current study. Male I. ricinus are feeding facultatively, taking small blood meals and remain on the host searching for females to mate [1]. Facultative feeding may explain why only two males were found individually in subcutaneous location. It cannot be ruled out that copulating males are separated from females during degradation process or preparation of ticks. Male Ixodes can remain in copulation for 6-11 days throughout the feeding periods of female Ixodes [35], which may also explain why I. ricinus mating pairs are found in the subcutaneous tissue. Rare findings of nymphs, and none of larvae, may be related to their shorter hypostome. Additionally, a shorter feeding duration of immature ticks may explain their absence. So far, the duration and mechanism causing the subcutaneous localization of ticks are unknown, but long feeding times of females seems to be crucial for penetration.

In this study, subcutaneous ticks were usually located at three predominant body parts: ears, axillar and inguinal area, which is in line with previous studies. Smith et al. [21] reported subcutaneous ticks in the inguinal, axillar and perianal region, while Drozdz [14] found ticks in subcutaneous location in the area of ears, shoulder and belly. Neither of these reports provide information about the frequency of occurrence. The present study identified the most significant infested body parts of red foxes. Strikingly, these body parts are less hairy, folded and the skin is thin. This is in concordance with ESCCAP Guidelines Control of Ectoparasites in Dogs and Cats, which generally found the same preferences for tick attachment in dogs and cats [36].
So far, the subcutaneous presence of ticks was mostly reported from red foxes [13-21] Only single case reports of subcutaneous ticks in raccoon dogs and from one single domestic dog exists at the moment $[22,23]$ In a study inspecting 134 roe deer furs from inside and outside, only external ticks were found and none in the subcutaneous tissue [37]. Thus far, little is currently known about this phenomenon, leaving questions concerning the mechanisms as to how ticks become subcutaneous and which animals can be affected.

Histological examination revealed that the quality of the inflammatory response is related to the stage of degradation of the tick. All subcutaneous ticks were surrounded by granulomatous panniculitis, these findings agree with D'Amico et al. [18]. When the exoskeleton was intact, the inflammation was mild-moderate. But in case of broken exoskeletons a severe inflammatory response was present. The one well-preserved tick showed an acute and local mechanical irritation of dermis and epidermis. This could be a sign that this tick has recently penetrated the skin. The inner part of the ticks' intact exoskeleton contained a mixture of cell debris and no cellular structure was recognizable, which may explain why DNA isolation was not successful.

\section{Conclusions}

Subcutaneous location of ticks seems to be very common in red foxes and is rather the rule than the exception. They were predominantly located at less hairy, thin and folded skin body parts of the fox. The unusual tick location is not linked to one tick species or development stage, however, mainly female longirostra were found. Decisive factors for the subcutaneous location of ticks appear to be the deep embedment of longirostra and long duration time of attachment of females. Further examinations are needed to evaluate the mechanism leading to the subcutaneous localization of ticks. Nevertheless, this phenomenon is not an evolutionary advantage for ticks, as all collected ticks were dead and at various stages of decomposition.

\footnotetext{
Abbreviations

Cl: Confidence interval; cox1: Cytochrome c oxidase subunit 1; DNA: Deoxyribonucleic acid; H\&E: Hematoxylin and eosin; PBS: Phosphate-buffered saline; PCR: Polymerase chain reaction; Rpm: Revolutions per minute; rRNA: Ribosomal ribonucleic acid; SD: Standard deviation.

\section{Acknowledgements}

We grateful acknowledge Andreas Leppmann, Josef Segbers, Peter Truch, Stefan Birka and all local hunters for providing the fox carcasses. Many thanks go to Gabriele Linder and Dana Rüster for help in the laboratory. Thanks to the Biolmaging Core Facility at the Saxon Incubator of Clinical Translation for microscopy and histological imaging. We also acknowledge Kristin Klose for
} 
help in describing the pathological changes. Publication of this paper has been sponsored by Bayer Animal Health in the framework of the 15th CVBD World Forum Symposium.

\section{Authors' contributions}

MP conceived the study. Animals and ticks were collected by $\mathrm{MH}$. MH, NK and $\mathrm{AO}$ carried out the morphological identification and nucleic acid extraction of the ticks. MH curated the data collection. JS and MH performed the histology. $\mathrm{MH}, \mathrm{AO}, \mathrm{NK}$ and MP drafted the manuscript. MH and $\mathrm{AO}$ carried out statistical analyses. All authors read and approved the final manuscript.

\section{Funding}

Parts of the study were funded by Pfizer Pharma GmbH, Berlin, Project No. WI244427.

\section{Availability of data and materials}

The data supporting the conclusions of this article are included within the article. The raw data used and/or analyzed during the present study are available from the corresponding author upon reasonable request.

\section{Ethics approval and consent to participate}

All hunted animals were collected in accordance with German Hunting Regulations, during the legal hunting season, and as part of legal hunting activities. No live animal was harmed for this study.

\section{Consent for publication}

Not applicable.

\section{Competing interests}

The authors declare that they have no competing interests.

\section{Author details Germany. \\ Received: 12 December 2019 Accepted: 1 April 2020 \\ Published online: 21 April 2020}

${ }^{1}$ Institute of Animal Hygiene and Veterinary Public Health, Faculty of Veterinary Medicine, University of Leipzig, An den Tierkliniken 1, 04103 Leipzig, Germany. ${ }^{2}$ Institute of Anatomy, Histology and Embryology, Faculty of Veterinary Medicine, University of Leipzig, An den Tierkliniken 43, 04103 Leipzig,

\section{References}

1. Oliver JH. Biology and systematics of ticks (Acari:|xodida). Annu Rev Ecol Syst. 1989;20:397-430.

2. Stanek G. Büchse der Pandora: Krankheitserreger in Ixodes ricinus-Zecken in Mitteleuropa. Wien Klin Wochenschr. 2009;121:673-83.

3. Cornely M, Schultz U. Zur Zeckenfauna Ostdeutschlands. Angew Parasitol. 1992:33:173-83.

4. Heidrich J. Prevalence of Borrelia burgdorferi sensu lato in red foxes (Vulpes vulpes) in eastern Brandenburg. Berlin: PhD Thesis, Freie Universität Berlin; 2000.

5. Liebisch A, Walter G. Ticks of domestic and wild animals in Germany: on the occurrence and biology of the hedgehog tick (Ixodes hexagonus) and the fox tick (Ixodes canisuga). Deutsche Tierärztliche Wochenschrift. 1986:93:447-50.

6. Schöffel I, Schein E, Wittstadt U, Hentsche J. Zur Parasitenfauna des Rotfuchses in Berlin (West). Berl Muench Tieraerztl Wochenschr. 1991;104:153-7.

7. Meyer-Kayser E, Hoffmann L, Silaghi C, Pfister K, Mahling M, Passos LMF. Dynamics of tick infestations in foxes in Thuringia, Germany. Ticks Tick Borne Dis. 2012;3:232-9.

8. Hornok S, Sándor AD, Beck R, Farkas R, Beati L, Kontschán J, et al. Contributions to the phylogeny of Ixodes (Pholeoixodes) canisuga, I. (Ph.) kaiseri, I. (Ph.) hexagonus and a simple pictorial key for the identification of their females. Parasit Vectors. 2017;10:545

9. Liebisch $\mathrm{G}$, Hoffmann L, Pfeifer F, Liebisch A. Ticks of the red fox and their significance for Lyme borreliosis. Zentralblatt für Bakteriologie. 1997:286:246-7.
10. Slovák M, Štibrániová I, Hajnická V, Nuttall PA. Antiplatelet-derived growthfactor (PDGF) activity in the saliva of ixodid ticks is linked with their longmouthparts. Parasite Immunol. 2014;36:32-42.

11. Marquardt WC, Kondratieff BC. Biology of disease vectors. 2nd ed. Burlington: Elsevier Academic Press; 2005

12. Gern L. Life cycle of Borrelia burgdorferi sensu lato and transmission to humans. Curr Probl Dermatol. 2009:37:18-30.

13. Nuttal GH. Penetration of /xodes beneath the skin. Parasitology. 1914:7:258-9.

14. Drozdz J. Penetration of Ixodes ricinus under the skin of the host. Acta Parasitol Polon. 1958;6:383-5.

15. Hiniday HK. Die Parasitenfauna des Rotfuchses, Vulpes vulpes (L.), in Österreich. Zbl Vet Med B. 1971;18:21-32

16. Lebeda M. Findings of Ixodes ricinus in the deep layers of the skin and in the lymphatic ganglion (lymph node) of foxes (Vulpes vulpes). Veterinarsky Casopis Bratislava. 1962;11:193-205.

17. Tovornik D. Penetration of ticks (Ixodidae) in the deep layers of the host's skin. Biol Vestnik. 1984:32:117-20.

18. D’Amico G, Juránková J, Tăbăran FA, Frgelecová L, Forejtek P, Matei IA, et al. Occurrence of ticks in the subcutaneous tissue of red foxes, Vulpes vulpes in Czech Republic and Romania. Ticks Tick Borne Dis. 2017;8:309-12.

19. Pet'ko B, Stanko M. Finding of the tick Ixodes ricinus under the skin of a fox in Slovakia. Folia Vet. 1991;21:159-62.

20. Dwużnik D. Ectoparasites of red fox Vulpes vulpes with peculiar focus on ticks in the subcutaneous tissues. Ann Parasitol. 2019:65:250.

21. Smith DD, Frenkel JK, Smith El. Intradermal infestation of a red fox (Vulpes vulpes) by the lone star tick (Amblyomma americanum). J Wildl Dis. 1986;22:122-4

22. Matysiak A, Wasielewski O, Włodarek J, Ondrejkova A, Tryjanowski P. First report of ticks in the subcutaneous tissue of the raccoon dog Nyctereutes procyonoides. Veterinarni Medicina. 2018:63:571-4.

23. Zakrisson G. Ticks, Ixodes ricinus in the sub-cutaneous tissues of a dog and foxes. Svensk Veterinärtidning. 2010;62:25-7.

24. Chang SH, Park J-H, Kwak JE, Joo M, Kim H, Chi JG, et al. A case of histologically diagnosed tick infestation on the scalp of a Korean child. Korean J Parasitol. 2006:44:157-61.

25. Lydecker HW, Banks PB, Hochuli DF. Counting ticks (Acari: Ixodida) on hosts is complex: a review and comparison of methods. J Med Entomol. 2019;56:1527-33

26. Estrada-Peña A, Mihalca AD, Petney T, editors. Ticks of Europe and North Africa: a guide to species identification. Cham: Springer; 2018.

27. LV J, Wu S, Zhang Y, Zhang T, Feng C, Jia G, et al. Development of a DNA barcoding system for the Ixodida (Acari: Ixodida). Mitochondrial DNA. 2013;25:142-9.

28. Otranto D, Cantacessi C, Dantas-Torres F, Brianti E, Pfeffer M, Genchi C, et al. The role of wild canids and felids in spreading parasites to dogs and cats in Europe Part II: helminths and arthropods. Vet Parasitol. 2015;213:24-37.

29. Lorusso V, Lia RP, Dantas-Torres F, Mallia E, Ravagnan S, Capelli G, et al. Ixodid ticks of road-killed wildlife species in southern Italy: new tick-host associations and locality records. Exp Appl Acarol. 2011:55:293-300.

30. Sándor AD, D'Amico G, Gherman CM, Dumitrache MO, Domșa C, Mihalca AD. Mesocarnivores and macroparasites: altitude and land use predict the ticks occurring on red foxes (Vulpes vulpes). Parasit Vectors. 2017;10:173.

31. Sobrino R, Millán J, Oleaga A, Gortázar C, de La Fuente J, Ruiz-Fons F. Ecological preferences of exophilic and endophilic ticks (Acari: Ixodidae) parasitizing wild carnivores in the Iberian Peninsula. Vet Parasitol. 2012:184:248-57.

32. Domínguez-Peñafiel G, Giménez-Pardo C, Gegúndez M, Lledó L. Prevalence of ectoparasitic arthropods on wild animals and cattle in the Las Merindades area (Burgos, Spain). Parasite. 2011;18:251-60.

33. Domínguez G. North Spain (Burgos) wild mammals ectoparasites. Parasite. 2004;11:267-72.

34. Meyer-Kayser E, Hoffmann L, Silaghi C, Passos LMF, Mahling M, Pfister K. Tick infestation of foxes in Thuringia with special focus on foxes with scabies. Vet Med Austria. 2011:98:292-6.

35. Kocan KM, de La Fuente J, Coburn LA. Insights into the development of Ixodes scapularis: a resource for research on a medically important tick species. Parasit Vectors. 2015:8:592. 
36. ESCCAP. ESCCAP Guideline 03 sixth edition - March 2018 - control of ectoparasites in dogs and cats. Malvern: ESCCAP; 2018. https://www. esccap.org/uploads/docs/mjy50wev_0720_ESCCAP_Guideline_GL3_ v9_1p.pdf. Accessed 10 Dec 2019.

37. Król N, Chitimia-Dobler L, Dobler G, Karliuk Y, Birka S, Obiegala A, Pfeffer M. Tick burden on European roe deer (Capreolus capreolus) from Saxony, Germany, and detection of tick-borne encephalitis virus in attached ticks. Parasitol Res. 2020. https://doi.org/10.1007/s00436-020-06637-z.

\section{Publisher's Note}

Springer Nature remains neutral with regard to jurisdictional claims in published maps and institutional affiliations.
Ready to submit your research? Choose BMC and benefit from:

- fast, convenient online submission

- thorough peer review by experienced researchers in your field

- rapid publication on acceptance

- support for research data, including large and complex data types

- gold Open Access which fosters wider collaboration and increased citations

- maximum visibility for your research: over 100M website views per year

At BMC, research is always in progress.

Learn more biomedcentral.com/submissions 